\title{
Kelayakan Usaha Tani Padi dan Sapi Potong Mendukung Pengembangan Sistem Integrasi Tanaman-Ternak di Kabupaten Merauke, Papua
}

\section{(Feasibility of Rice and Cattle Farming to Support the Development of Integrated Crops-Livestock System in Merauke, Papua)}

\author{
Usman $^{1}$, Tirajoh $\mathrm{S}^{1}$, Baliadi $\mathrm{Y}^{1}$, Rauf $\mathrm{AW}^{2}$ \\ ${ }^{1}$ Balai Pengkajian Teknologi Pertanian Papua, Jl. Yahim No. 49, Sentani, Jayapura \\ ${ }^{2}$ Balai Pengkajian Teknologi Pertanian Sulawesi Selatan \\ Jl. Perintis Kemerdekaan, Km. 17,5, Sudiang, Makassar, Sulawesi Selatan 90245 \\ usmanrauna@yahoo.com
}

\begin{abstract}
Merauke District is the center of rice development with the high potential of dry matter rice straw as cattle feed up to $62,123.25$ ton/year. The study was aimed to analyze the feasibility of rice and cattle farming to support the development of integrated crop-livestock systems in Merauke. The study was conducted at two farmers locations namely Tanah Miring and Kurik District. The results showed that rice production and cattle weight of both systems (introduction and existing) was 4.43 tons/ha (ADG $37.46 \mathrm{~kg} / \mathrm{head}$ ) and 3.71 tons/ha (ADG $37.1 \mathrm{~kg} / \mathrm{head}$ ), respectively. The feasibility analysis shows that both system, have $\mathrm{R} / \mathrm{C}>1$ value. But the $\mathrm{R} / \mathrm{C}$ value of introduction pattern, integrated rice, and cattle farming was higher compared to the existing pattern. The value of MBCR $>2$ on the introduction pattern supports that the introducing technology is a key factor in increasing of rice production and cattle weight. Concluded that introduction pattern more profitable than the existing pattern.
\end{abstract}

Key Words: Integration, Rice, Beef Cattle, Rice Straw, Feasibility

\begin{abstract}
ABSTRAK
Kabupaten Merauke merupakan sentra pengembangan tanaman padi dengan potensi produksi bahan kering jerami padi yang dapat dimanfaatkan sebagai pakan sapi potong sebesar $62.123,25$ ton/tahun. Kajian bertujuan menganalisis kelayakan usahatani padi dan sapi potong dalam mendukung pengembangan sistem integrasi tanaman-ternak di Kabupaten Merauke. Kegiatan usahatani padi dan sapi potong dilaksanakan secara on farm di lahan petani pada dua lokasi yang berbeda yaitu Tanah Miring dan Kurik. Berdasarkan hasil kajian diperoleh produksi padi dan pertambahan berat badan sapi potong pada pola introduksi dan pola existing, berturut-turut adalah 4,43 ton/ha (PBBH 37,46 kg/ekor) dan 3,71 ton/ha (PBBH 37,1 kg/ekor). Analisis kelayakan usaha tani menunjukkan bahwa baik pola introduksi maupun pola existing diperoleh nilai $\mathrm{R} / \mathrm{C}>1$. Tetapi nilai $\mathrm{R} / \mathrm{C}$ pola introduksi lebih tinggi dibandingkan dengan pola existing. Nilai MBCR >2 menunjukkan bahwa teknologi yang diintroduksikan pada pola introduksi memberikan tambahan keuntungan 2 kali lipat dari pola existing. Disimpulkan bahwa pola introduksi lebih menguntungkan dibandingkan dengan pola existing.
\end{abstract}

Kata Kunci:Integrasi, Padi, Sapi Potong, Bahan Kering, Kelayakan Usaha

\section{PENDAHULUAN}

Kabupaten Merauke merupakan sentra pengembangan tanaman padi di Kawasan Timur Indonesia, khususnya di Provinsi Papua. Sebagai penghasil padi terbesar di Papua, selama lima tahun terakhir (tahun 2010-2013) produksi padi terus mengalami peningkatan dengan tingkat pertumbuhan rata-rata sebesar 12,45\%/tahun. Pada tahun 2013 produksi padi mencapai 177.581 ton, dengan produksi tertinggi di Distrik Tanah Miring (56.444 
ton) (BPS Kabupaten Merauke 2015). Salah satu permasalahan yang dihadapi petani adalah sulitnya memperoleh pupuk anorganik di waktu yang tepat dan kurangnya pemahaman petani terhadap pengolahan pupuk kandang menjadi pupuk organik bagi tanaman padi.

Produk samping berupa jerami padi belum dimanfaatkan oleh petani/peternak sebagai pakan sapi potong secara optimal. Jerami padi pada umumnya dibakar di lahan sawah. Potensi jerami padi yang dapat dihasilkan dari luas panen sebesar 35.499 ha mencapai 62.123,25 t/tahun (Usman et al. 2016). Beberapa faktor penyebab belum dimanfaatkannya jerami padi sebagai pakan ternak, di antaranya kurangnya pengetahuan teknologi pemanfaatan jerami sebagai pakan.

Populasi sapi potong di Merauke mencapai 33.037 ekor (Disnak Kabupaten Merauke 2015). Tingkat pertumbuhannya terus menurun karena rendahnya produktivitas ternak dan tingginya kematian ternak terutama di musim kemarau. Rendahnya produktivitas ternak ruminansia besar, karena petani/peternak sulit memperoleh hijauan pakan dan air minum di musim kemarau. Selain itu potensi pupuk kandang yang dihasilkan belum dimanfaatkan sebagai pupuk organik bagi tanaman padi.

Oleh karena itu, pengembangan sistem integrasi tanaman-ternak (SITT) penting untuk diterapkan agar pupuk kandang (Pukan) yang dihasilkan dapat dimanfaatkan sebagai pupuk organik bagi tanaman padi dan jerami padi sebagai pakan ternak sapi potong, mengarah ke paradigma agribisnis (Mulyadi et al. 2013). Makalah ini bertujuan menganalisis kelayakan usaha tani padi dan sapi potong dalam mendukung pengembangan sistem integrasi tanaman-ternak di Kabupaten Merauke, Papua.

\section{MATERI DAN METODE}

Kajian dilaksanakan secara on farm di lahan petani di Kabupaten Merauke di dua lokasi yaitu Desa Wonorejo Distrik Tanah Miring dan Desa Sumber Harapan Distrik Kurik. Penentuan petani kooperator dilakukan secara sengaja (purposive sampling). Petani yang terpilih adalah petani yang melaksanakan usaha tani padi dan ternak sapi. Petani yang dipilih di setiap lokasi terdiri dari pola introduksi dan pola existing. Penerapan paket teknologi budidaya padi dan sapi potong terbagi atas dua pola usaha tani yaitu pola introduksi dan pola existing. Paket teknologi yang diterapkan disajikan pada Tabel 1.

Sistem pemeliharaan ternak sapi pada pola introduksi dilakukan secara intensif dengan pakan utama jerami padi fermentasi. Kegiatan usaha tani padi adalah pemanfaatan pupuk kandang sebagai pupuk organik. Pola existing (petani) adalah kebiasaan petani dalam memelihara ternak. Kelayakan usahatani dikaji berdasarkan data aspek teknis berupa produksi tanaman padi, dan pertambahan bobot sapi. Sedangkan aspek ekonomi berupa biaya produksi, pendapatan dan keuntungan usaha tani. Data yang telah dikumpulkan ditabulasi dan dianalisis secara deskriptif. Analisis kelayakan usaha tani pola introduksi dengan pola petani dilakukan analisis $\mathrm{R} / \mathrm{C}$ ratio dan untuk membandingkan tingkat pendapatan yang diperoleh dengan analisis MBCR (marginal benefit cost ratio) (Hendayana 2006) sebagai berikut:

$$
\mathrm{MBCR}=\frac{\text { Keuntungan teknologi introduksi }- \text { Keuntungan teknologi petani }}{\text { Biaya teknologi introduksi }- \text { Biaya teknologi petani }}
$$

Kriteria:

MBCR : 1 teknologi pola introduksi tidak memberikan tambahan penerimaan dibandingkan teknologi pola existing

MBCR : $\geq 2$ teknologi pola introduksi layak direkomendasikan untuk menggantikan pola existing. 
Tabel 1. Paket teknologi pola introduksi dan pola existing di Kabupaten Merauke

\begin{tabular}{|c|c|c|}
\hline Pola usaha tani & Pola introduksi & Pola existing \\
\hline \multicolumn{3}{|l|}{ Budidaya Padi } \\
\hline Varietas & IR 66 & IR 66 \\
\hline \multicolumn{3}{|l|}{ Dosis Pupuk (kg/ha) } \\
\hline Urea & 150 & 150 \\
\hline SP36 & 100 & 100 \\
\hline Pupuk kandang (Pukan) & 5.000 & 0 \\
\hline \multicolumn{3}{|l|}{ Pestisida } \\
\hline Karbofuran & Diberikan & diberikan \\
\hline BBMC & Diberikan & diberikan \\
\hline Klor pirifos & di berikan & tidak di berikan \\
\hline \multicolumn{3}{|l|}{ Budidaya Sapi Potong } \\
\hline Jenis sapi potong & $\mathrm{PO}$ & $\mathrm{PO}$ \\
\hline Pemeliharaan & dikandangkan & di lepas \\
\hline \multicolumn{3}{|l|}{ Komposisi pakan (kg/ekor) : } \\
\hline Rumput lapangan & 5,00 & 15,00 \\
\hline Jerami padi fermentasi & 10,00 & 0 \\
\hline Bekatul & 2,00 & 0 \\
\hline Garam & 1,25 & 0 \\
\hline Air minum & ad libitum & ad libitum \\
\hline \multicolumn{3}{|l|}{ Pengolahan limbah } \\
\hline Jerami padi & dimanfaatkan & tidak dimanfaatkan \\
\hline Kotoran ternak & dimanfaatkan & tidak dimanfaatkan \\
\hline
\end{tabular}

\section{HASIL DAN PEMBAHASAN}

\section{Pemanfaatan pukan dan jerami padi}

Hasil kajian menunjukkan bahwa pemanfaatan pukan sebagai pupuk organik dan jerami padi sebagai pakan dapat meningkatkan produktivitas padi dan sapi potong (Tabel 2).

Tabel 2. Hasil usaha tani padi dan sapi potong pada pola introduksi dan pola existing

\begin{tabular}{lcc}
\hline \hline Usaha tani & Pola introduksi & Pola existing \\
\hline Padi (ton/ha) & 4,43 & 3,71 \\
Sapi potong: & & \\
PBB (kg/ekor) & 37,46 & 37,10 \\
PBBH (kg/ekor/hari) & 0,37 & 0,37 \\
\hline
\end{tabular}

Pada Tabel 2 ditunjukkan bahwa pola introduksi memberikan hasil padi sebesar 4,43 ton/ha dan 3,71 ton/ha di pola existing. Hal ini menunjukkan bahwa pemanfaatan pukan mampu meningkatkan hasil produksi padi sebesar 0,72 ton/ha $(19,41 \%)$ dari pola existing. Hasil ini lebih tinggi dibandingkan dengan yang dilaporkan Zaini et al. (2002) yaitu peningkatan produksi tanaman padi sebesar 0,55 ton/ha pada musim tanam pertama dan 0,30 ton/ha pada musim tanam kedua dan hasil kajian Kariyasa \& Pasandaran (2004) 
dengan peningkatan $6,9-8,8 \%$. Basuni et al. (2010) melaporkan sistem integrasi padi dengan sapi potong memberikan hasil produksi padi 5,34 ton/ha, dengan dosis pupuk kandang 2 ton/ha. Hal ini secara ekonomi petani kooperator dapat menurunkan penggunaan pupuk anorganik sebesar $57,14 \%$.

Hasil kajian menunjukkan bahwa pemberian jerami fermentasi $10 \mathrm{~kg} / \mathrm{ekor} / \mathrm{hari}$ dan hijauan $5 \mathrm{~kg} / \mathrm{ekor} / \mathrm{hari}$ pada ternak sapi pada pola introduksi memberikan PBBH yang tidak berbeda dengan pola petani. Hal ini karena belum beradaptasinya ternak sapi dengan baik terhadap perlakuan pakan dan pola pemeliharaan yang diberikan. Hasil penelitian Darmawan (2003) menunjukkan bahwa pemberian jerami fermentasi $6 \mathrm{~kg} / \mathrm{ekor} / \mathrm{hari}$ dan dedak $3 \mathrm{~kg} / \mathrm{ekor} /$ hari memberikan PBBH sebesar 0,43 kg/ekor, sedangkan Galib et al. (2006) dengan pemberian jerami fermentasi 6-8 kg/ekor/hari dan dedak $1 \mathrm{~kg} / \mathrm{ekor} / \mathrm{hari}$ memberikan PBBH sebesar $0,41 \mathrm{~kg} / \mathrm{ekor}$. Hal ini menunjukkan bahwa pemanfaatan jerami padi sebagai pakan di lokasi ini perlu dilanjutkan khususnya dalam pengembangan sapi potong selain dapat mengatasi ketersediaan pakan di musim kemarau. Menurut Kariyasa (2003), pemanfaatan jerami padi dapat mengatasi permasalahan ketersediaan pakan berkisar 33,3 persen dari total rumput yang dibutuhkan. Model SITT yang dikembangkan petani di Jawa Tengah dan Jawa Timur mampu mengurangi penggunaan pupuk anorganik 25-35\% dan meningkatkan produktivitas padi 20 - 29\% (Adnyana 2003).

\section{Analisis kelayakan usaha tani}

Hasil analisis usaha tani padi (Tabel 3) menunjukkan bahwa jumlah keuntungan bersih yang diterima oleh petani pada pola introduksi ( $\mathrm{Rp} 3.912 .500)$ lebih tinggi dari pola existing ( $\mathrm{Rp}$ 3.178.000). Lebih tingginya keuntungan pada pola introduksi berasal dari lebih tingginya hasil produksi. Di samping itu pemberian pukan pada lahan sawah dapat memperbaiki struktur tanah menjadi lebih subur, sehingga hal ini juga merupakan suatu keuntungan ekonomi yang diperoleh pada pola introduksi. Nilai $\mathrm{R} / \mathrm{C}>1$, baik pada pola introduksi maupun pada pola existing, artinya kedua pola usaha tani padi tersebut layak untuk dilaksanakan. Namun, nilai kelayakan usaha padi yang diperoleh pada pola introduksi $(1,96)$ lebih tinggi dibandingkan dengan pola existing $(1,91)$. Hal ini menunjukkan bahwa tingkat penerimaan yang diperoleh pada pola introduksi lebih tinggi dari pola existing.

Nilai MBCR sebesar 1,31 menunjukkan bahwa besarnya tambahan keuntungan yang diperoleh pada pola introduksi sebesar 1,31 kali lipat dibandingkan dengan nilai tambah yang diperoleh pada pola existing. Artinya setiap penambahan biaya sebesar Rp 1.000 akibat perubahan pola existing dengan pola introduksi akan menyebabkan penambahan penerimaan sebesar Rp 1.310. Hal ini menunjukkan bahwa secara teknis inovasi teknologi yang diintroduksikan pada pola introduksi layak untuk menggantikan pola existing yang selama ini dilaksanakan oleh petani. Hasil kajian usaha tani sapi potong (Tabel 3) menunjukkan bahwa pola introduksi memberikan keuntungan lebih tinggi dibandingkan dengan pola existing. Tingkat keuntungan yang tinggi pada pola introduksi, selain karena dipengaruhi oleh PBBH juga nilai tambah dari hasil penjualan dedak, jerami dan pukan.

Pola introduksi maupun pola existing memberikan nilai $\mathrm{R} / \mathrm{C}>1$, artinya keduanya layak untuk dilaksanakan. Hasil analisis MBCR diperoleh nilai MBCR sebesar 1,55 menujukkan bahwa tambahan keuntungan yang diperoleh pada pola introduksi 1,55 kali lipat dibandingkan dengan tambahan biaya pola existing. Artinya setiap penambahan biaya sebesar Rp 1.000 akibat perubahan pola existing dengan pola introduksi akan menyebabkan penambahan keuntungan sebesar Rp. 1.550. Oleh karena itu, pola existing yang selama ini dilaksanakan oleh petani sudah selayaknya ditingkatkan melalui penerapan inovasi teknologi. Di lain sisi, penerapan inovasi teknologi sistem integrasi padi 
dan sapi potong tidak dapat dilaksanakan secara optimal, karena masih mengalami permasalahan atau kesulitan ditingkat petani (pengguna) terkait pengalokasian tenaga kerja. Pemanfaatan limbah jerami sebagai pakan khususnya pada musim kemarau mampu menghemat tenaga kerja dalam kegiatan mencari rumput, namun demikian dalam pengelolaan jerami untuk dapat digunakan sebagai pakan juga butuh tenaga kerja (Kariyasa 2005).

Tabel 3. Analisis usahatani padi dan sapi potong pola introduksi dan pola existing di Kabupaten Merauke

\begin{tabular}{|c|c|c|}
\hline Uraian & Pola introduksi & Pola existing \\
\hline \multicolumn{3}{|l|}{ Usaha tani padi } \\
\hline \multicolumn{3}{|l|}{ Biaya produksi (Rp/ha) } \\
\hline Benih & $225.000,00$ & $225.000,00$ \\
\hline Pupuk anorganik & $375.000,00$ & $425.000,00$ \\
\hline Pupuk kandang & $500.000,00$ & - \\
\hline Pestisida & $624.000,00$ & $562.500,00$ \\
\hline Tenaga kerja & $2.337 .500,00$ & $2.287 .500,00$ \\
\hline Jumlah & $4.061 .500,00$ & $3.500 .000,00$ \\
\hline Penerimaan (Rp/ha) & $7.974 .000,00$ & $6.678 .000,00$ \\
\hline Keuntungan(Rp/ha) & $3.912 .500,00$ & $3.178 .000,00$ \\
\hline $\mathrm{R} / \mathrm{C}$ & 1,96 & 1,91 \\
\hline MBCR & 1,31 & \\
\hline \multicolumn{3}{|l|}{ Usahatani sapi potong } \\
\hline \multicolumn{3}{|c|}{ Biaya produksi (Rp/ekor) } \\
\hline Perkandangan & $500.000,00$ & $250.000,00$ \\
\hline Pakan & $200.000,00$ & $150.000,00$ \\
\hline Obat-obatan & $200.000,00$ & $150.000,00$ \\
\hline Tenaga kerja & $525.000,00$ & $550.000,00$ \\
\hline Jumlah & $1.425 .000,00$ & $1.100 .000,00$ \\
\hline \multicolumn{3}{|l|}{ Penerimaan (Rp/ekor) } \\
\hline Nilai ternak & $1.875 .000,00$ & $1.855 .000,00$ \\
\hline Jerami padi & $350.000,00$ & - \\
\hline Dedak padi & $235.000,00$ & - \\
\hline Pupuk kandang & $225.000,00$ & - \\
\hline Jumlah & $2.685 .000,00$ & $1.855 .000,00$ \\
\hline Keuntungan (Rp/ekor) & $1.260 .000,00$ & $755.000,00$ \\
\hline $\mathrm{R} / \mathrm{C}$ & 1,88 & 1,69 \\
\hline MBCR & 1,55 & \\
\hline
\end{tabular}

\section{KESIMPULAN}

Sistem integrasi tanaman ternak, pada pola introduksi dalam usaha tani padi dan ternak sapi memberikan keuntungan masing-masing sebesar $\mathrm{Rp} 3.912 .500$ dan $\mathrm{Rp}$ 1.260.000, lebih tinggi dibandingkan dengan pola existing pada usaha tani padi dan ternak sapi yang memberikan keuntungan masing-masing sebesar Rp 3.178.000 dan Rp 755.000, 
sehingga pola introduksi lebih layak menggantikan pola existing, karena memberikan keuntungan lebih tinggi di sisi finansial dan lebih ramah lingkungan serta berkelanjutan.

\section{UCAPAN TERIMA KASIH}

Ucapan terima kasih kami sampaikan Kepada Dinas Pertanian Tanaman Pangan dan Disnak Kabupaten Merauke serta teman-teman teknisi di Kebun Percobaan (KP) Merauke yang telah membantu selama pelaksanaan kegiatan berlangsung.

\section{DAFTAR PUSTAKA}

Adnyana MO. 2003. Pengkajian dan Sintesis kebijakan pengembangan peningkatan produktivitas padi dan ternak (P3T) ke depan. Bogor (Indonesia): Pusat Penelitian dan Pengembangan Tanaman Pangan.

Basuni R, Muladno C, Suryahadi. 2010. Model sistem integrasi padi-sapi potong di lahan sawah. Forum Pascasarjana IPB. 33:177-190.

BPS Kabupaten Merauke. 2015. Merauke Dalam Angka. Merauke (Indonesia): Badan Pusat Statistik Kabupaten Merauke.

Darmawan A. 2003. Keragaan sistem integrasi padi ternak di Kalimantan Selatan (studi kasus di Desa Mandala Kabupaten Hulu Sungai Selatan dan Desa Panggalaman Kabupaten Banjar). Banjarbaru (Indonesia): Balai Pengkajian Teknologi Pertanian Kalimantan Selatan.

Disnak Kabupaten Merauke. 2015. Laporan Tahunan Dinas Peternakan Kabupaten Merauke.

Galib R, Sumanto, Suryana, Subhan A, Zuraida R, Pribadi Y, Darwis M, Darmawan A. 2006. Kajian pengembangan sistem integrasi padi - sapi di lahan sawah tadah hujan Kalimantan Selatan. Banjarbaru (Indonesia): Balai Pengkajian Teknologi Pertanian Kalimantan Selatan.

Hendayana R. 2006. Dampak penerapan teknologi terhadap perubahan struktur biaya dan pendapatan usahatani padi. Dalam: Amiruddin Syam, editor. Prosiding Seminar Nasional prosiding seminar nasional dan ekspose hasil penelitian. Akselerasi Inovasi Teknologi Spesifik Lokasi Menuju Pertanian Berkelanjutan. Kendari, 18-19 Juli 2005. Bogor (Indonesia): Balai Besar Pengkajian dan Pengembangan Teknologi Pertanian. hlm. 135-143.

Kariyasa K. 2003. Hasil Laporan Pra Survei Kelembagaan Usahatani Tanaman Ternak Terpadu dalam Sistem dan Usaha Agribisnis. Jakarta (Indonesia): Proyek PAATP.

Kariyasa K, Pasandaran E. 2004. Dinamika struktur usaha dan pendapatan tanaman ternak terpadu. Makalah disampaikan dalam Seminar Kelembagaan Usahatani Tanaman Ternak Tanggal 30 November - 2 Desember 2004 di Denpasar, Bali. Jakarta (Indonesia): Proyek PAATP.

Kariyasa K. 2005. Sistem integrasi tanaman-ternak dalam perspektif reorientasi kebijakan subsidi pupuk dan peningkatan pendapatan petani. J Anal Kebijak Pertan. 3:68-80.

Mulyadi A, Wihardjaka, Setyanto P. 2013. Pengelolaan biogas dari integrasi tanaman pangan dan ternak sapi pada lahan sawah tadah hujan. Dalam: Djufry F, Baco D, Limbongan J, Sahardi Sariubang M, Ella A, Tandisau P, Nappu MB Ishak ABL, penyunting. Prosiding expose dan seminar nasional. Inovasi Pertanian Ramah Lingkungan. Makassar, 19-21 Juni 2013. hlm. 685-693.

Usman, Tirajoh S, Tiro BMW, Haloho. 2016. Potensi jerami padi sebagai sumber pakan ternak ruminansia besar dalam mendukung pengembangan integrasi tanaman-ternak di Kabupaten Merauke, Papua. Dalam: Ibrahim TM, Hermanto C, Musfal, Yusuf A, Nainggolan P, Haloho L, Asmanizar, Sumantri SE, Nuh M, penyunting. Prosiding Seminar Nasional Padi. Membangun Pertanian Berkelanjutan Mendukung Kedaulatan Pangan Nasional. Medan, 2 Desember 2015. Medan (Indonesia): BPTP Sumatera Utara. hlm. 353-359. 
Zaini Z, Las I, Suwarno, Haryanto B, Suntoro, Winanto EE. 2002. Pedoman Umum: Kegiatan Percontohan Peningkatan Produktivitas Padi Terpadu 2002. Jakarta (Indonesia): Badan Penelitian dan Pengembangan Pertanian.

\section{DISKUSI}

\section{Pertanyaan}

1. Apakah bahan mikroba yang digunakan untuk fermentasi?

2. Apakah ada pupuk yang digunakan dalam introduksi teknologi?

\section{Jawaban}

1. Fermentasi jerami padi menggunakan probion.

2. Pupuk anorganik dan pupuk organik dengan pemanfaatan limbah ternak. 